\title{
RELATIONSHIP BETWEEN SLEEP QUALITY AND HYPERTENSION AMONG WORKING-AGE POPULATION IN INDONESIA
}

\author{
Arwan Setyo Nugroho ${ }^{1}$, Erni Astutik ${ }^{2 *}$, Ferry Efendi ${ }^{3,4}$ \\ ${ }^{1}$ Department of Epidemiology, Faculty of Public Health, Universitas Airlangga, Surabaya, Indonesia \\ ${ }^{2}$ Research Group for Health and Wellbeing, Department of Epidemiology, Faculty of Public Health, \\ Universitas Airlangga, Surabaya, Indonesia \\ ${ }^{3}$ Faculty of Nursing, Universitas Airlangga, Surabaya, Indonesia \\ ${ }^{4}$ School of Nursing \& Midwifery, La Trobe University, Melbourne, Australia
}

Email*: erniastutik@fkm.unair.ac.id

\begin{abstract}
Introduction: One of the diseases which are continuously becoming a public health problem is hypertension. The prevalence of hypertension in working-age or productive age in Indonesia has increased significantly in recent years. There are many risk factors for hypertension in adults, one of which is lack of sleep. Sleep disorders can increase the risk of hypertension. This study aimed at finding out the relationship between sleep quality and the incidence of hypertension among the working-age population in Indonesia. Methods: This study utilized secondary data from the Indonesia Family Life Survey (IFLS) 5 data with a cross-sectional study design. The sample in IFLS 5 was taken using Multistage random sampling. The number of samples was 8,815 with inclusion criteria, which included that respondents were 15-64 years old and had complete data on the variables studied, namely: age, sex, sleep quality, physical activity, Body Mass Index (BMI), smoking habits and hypertension. Data were analyzed using multiple logistic regression. Results: Respondents with poor sleep quality had 1.39 higher odds of experiencing hypertension compared to respondents who had good sleep quality after being controlled by variables of gender, age, smoking status, physical activity, and nutritional status. (Poor-good sleep quality $=1.39,95 \%$ CI 1.20-1.61 p=0.000). Conclusions: It is necessary to strengthen information about health promotion regarding the prevention of hypertension in the community, especially good time management, to maintain sleep quality and the need for health programs on prevention of hypertension carried out by the ministry of health to the community through existing health-workers.
\end{abstract}

Keywords: hypertension; IFLS; sleep quality; working-age

\section{INTRODUCTION}

Increased systolic blood pressure of more than $140 \mathrm{mmHg}$ and or systolic blood pressure of more than $90 \mathrm{mmHg}$ is the definition of hypertension. Hypertension can cause damage to organs if it is not detected and not treated properly (National Heart et al., 2003). Hypertension sufferers are usually not aware of most of its signs and symptoms(Martuti, 2009). Recently, World Health Organization (WHO) projects that deaths from cardiovascular disease are increasing every year. In 2030, the mortality from cardiovascular disease is expected to reach 24\% (World Health Organization, 2013). Increased risk of heart, brain, kidney and other diseases caused by hypertension. In addition, premature deaths throughout the world are also caused by hypertension. WHO predicts that people suffering from hypertension worldwide number 1.13 billion and the number of people suffering from hypertension in low and middle income countries accounts for $2 / 3$ of the total number of sufferers worldwide. In 2025 the WHO targets the prevalence of hypertension in the world to be reduced by $25 \%$ (World Health Organization, 2020).

The prevalence of hypertension in Indonesia has increased every year. From $25.8 \%$ in 2013 , it increased to $34.1 \%$ in 2018 . Furthermore, the prevalence of hypertension among the working-age population in Indonesia has also increased every year. The prevalence of hypertension in the working-age group in Indonesia in 2013 was $25.94 \%$, which increased to $33.10 \%$ in 2018 (Kementerian Kesehatan Republik Indonesia, 2019). A research conducted by Mahiroh, Astutik \& Pratama (2019) from IFLS 5 data found that 
$22.63 \%$ of respondents aged $\geq 15$ years experienced hypertension (Mahiroh et al., 2019).

High blood pressure can be affected by poor sleep quality, short sleep time, and sleep disturbance (Javaheri et al., 2018). This is in line with a research conducted by Setiawan (2016) which affirmed that disturbed sleep patterns result in health problems. Hypertension is one of the issues due to the disturbance of this sleep pattern (Setiawan \& Purnomo, 2016). Cardiovascular disorders caused by endocrine disruption and metabolism due to short sleep time (Javaheri et al., 2008). The increased risk of hypertension occurs due to disturbed physiological and psychological balance of a person caused by poor sleep patterns. The strong stressor or suggestion that leads to organs that influence hypertension is one of the determinants of the strong influence of sleep patterns with the incidence of hypertension (Gangwisch et al., 2006).

Insignificant changes in cardiac output at night experienced by someone are the effect of sympathetic activity in blood vessels. It causes a relationship between sleep and hypertension. A decrease in normal nocturnal arterial blood pressure can occur due to decreased peripheral vascular resistance. There is a significant increase in the difference between sympathetic nerve activity and Rapid Eye Movement (REM) when a person wakes up and sleeps. Sensitivity is increased during sleeping. When the REM has passed, the blood pressure is almost close to the conscious level. Increased blood pressure maintenance during the REM period starts at the end of the sleep period from the night before is more useful to do because sleep patterns are very influential in this. Hypertension can occur due to hypertension disorders that occur in sleep quality and non-dipping prehypertension caused by abnormal sleep (Liu et al., 2016).

Many other studies examine the quality of sleep with the incidence of hypertension, but the research on sleep quality with the prevalence of hypertension using
IFLS data is rarely done. Therefore, the researchers are interested in conducting a study that aims to see whether there is a relationship between sleep quality and hypertension among working-age in Indonesia.

\section{METHODS}

This study utilized a cross-sectional study design. The data used were secondary data from the Indonesia Family Life Survey (IFLS) 5. IFLS 5 data in this study had been reviewed by the United States Research And Development (RAND) through Institutional Review Boards (IRBs) and also by Indonesia through Universitas Gadjah Mada. Furthermore, IFLS 5 data had received informed consent from all respondents.

The sample in IFLS 5 was taken using Multistage random sampling. Of 34,262 people interviewed at IFLS 5, 31,661 people met the criteria aged 15-64 years and were clear from missing data. The next step was checking the completeness of data from the variables of sleep quality, blood pressure, gender, age, physical activity, smoking habits, and body mass index in which a sample of 8,815 people was obtained.

The hypertension variable was obtained from direct interviews with respondents regarding chronic conditions of hypertension that had been diagnosed by health workers using the IFLS questionnaire form provided (book 3B code CD05). The result of weight measurement $(\mathrm{kg})$ divided by the respondent's height $\left(\mathrm{m}^{2}\right)$ was a way to measure the Body Mass Index (BMI) variable in this study. Camry model EB1003 scales and plastic height boards model 213 were used in measuring weight and height. If a person's body mass index was $\geq 30 \mathrm{~kg} / \mathrm{m}^{2}$ then he/she was declared obese, and his/her body mass < $30 \mathrm{~kg} / \mathrm{m}^{2}$, then he/she was declared not obese(World Health Organization, 2019).

In this study, sex or gender was divided into two: male and female, while the grouping of sleep quality was divided into two, namely good sleep quality and poor sleep 
quality. Moreover, smoking habit variables were grouped into three categories: 'smoke' (still smoking until now), 'used to smoke' (used to smoke, but now he had stopped smoking), and 'do not smoke' (never smoked at all). In the age group, the researchers divided the respondents into four categories, namely age $15-26$ years, $27-38$ years, age 39 50 years, and 51-64 years.

In this study, the International Physical Activity Questionnaire (IPAQ) scoring protocol is a way to measure physical activity. Physical activity is divided into three categories, namely low physical activity, moderate physical activity, and high physical activity. If the scoring result is less than 600 then the person is in the category of low physical activity; if the scoring result is 6002900600 then the person is in the moderate physical activity category; and if the scoring result is 3000 or more than 3000 , then the person is included in the category of high physical activity (Forde, 2005). The determination of low, moderate, or high categories was made based on the results of the calculation of activities carried out by the respondents; it was the duration of activity and frequency of activities carried out within a week. Using the IPAQ scoring protocol: if the activities carried out were in the category of low physical activity, the results were multiplied by 3.3 ; if the activities carried out were included in the category of moderate physical activity, the results were multiplied by 4 , and if the activities carried out were categorized as high physical activity, the results were multiplied by 8 . Furthermore, the results of the scoring were used to determine

Table 1. Distribution of respondents based on age, sex, quality of sleep, physical activity, BMI and smoking habits in Indonesia

\begin{tabular}{llll}
\hline Variables & Frequency & Percentage $(\%)$ & p-value \\
\hline Age & 2593 & 29.41 & 0.000 \\
$15-26$ & 3043 & 34.52 & \\
$27-38$ & 1928 & 21.87 & \\
$39-50$ & 1251 & 14.20 & \\
$51-64$ & & & 0.000 \\
\hline Sex & 4092 & 46.42 & \\
Male & 4723 & 53.58 & 0.009 \\
Female & & & \\
Sleep Quality & 6602 & 74.90 & 0.937 \\
Good & 2213 & 25.10 & \\
Poor & & & \\
\hline Physical activity & 2099 & 23.81 & 0.000 \\
Low & 3530 & 40.05 & \\
Moderate & 3186 & 36.14 & \\
High & & & \\
\hline IMT & 8096 & 91.84 & \\
Not suffer from obesity & 719 & 8.16 & \\
Suffer from obesity & & & \\
\hline Smoking habit & 5511 & 62.52 & \\
Do not smoke & 323 & 3.67 & \\
Used to smoke & 2981 & 33.81 & \\
Smoke & & & \\
\hline & & & \\
\hline
\end{tabular}


the categories of respondents' physical activity.

Variables of age, smoking habits, and sleep quality were obtained from direct interviews using the IFLS questionnaire form provided. On the smoking habit variable, the researchers grouped them into three categories: 'smoke' (still smoking until now), 'used to smoke' (used to smoke, but now he had stopped smoking), and 'do not smoke' (never smoked at all). In the age group, the researchers divided the respondents into four categories, namely age 15-26 years, 27-38 years, age 39-50 years, and 51-64 years. In addition, sleep quality was divided into two: good sleep quality and poor sleep quality. Data were analyzed using multiple logistic regression using STATA 14 software.

\section{RESULTS}

Table 2. The relationship between age, sex, sleep quality, physical activity, BMI and smoking habits with the incidence of hypertension in Indonesia

\begin{tabular}{|c|c|c|c|c|c|c|}
\hline \multirow[t]{2}{*}{ Variables } & \multicolumn{2}{|c|}{ Hypertension } & \multicolumn{2}{|c|}{ Not hypertension } & \multirow[t]{2}{*}{ OR } & \multirow{2}{*}{$\begin{array}{l}95 \% \text { CI } \\
\text { Lower Upper }\end{array}$} \\
\hline & $\mathrm{n}$ & $\%$ & $\mathrm{n}$ & $\%$ & & \\
\hline \multicolumn{7}{|l|}{ Sleep Quality } \\
\hline Good & 836 & 12.66 & 5766 & 87.34 & Ref & \\
\hline Poor & 328 & 14.82 & 1885 & 85.18 & 1.20 & $1.04-1.37$ \\
\hline \multicolumn{7}{|l|}{ Sex } \\
\hline Male & 416 & 10.17 & 3676 & 89.83 & Ref & \\
\hline Female & 748 & 15.84 & 3975 & 84.16 & 1.66 & $1.46-1.88$ \\
\hline \multicolumn{7}{|l|}{ Age } \\
\hline $15-26$ yo & 121 & 4.67 & 2472 & 95.33 & Ref & \\
\hline $27-38$ yo & 265 & 8.71 & 2778 & 91.29 & 1.94 & $1.56-2.43$ \\
\hline $39-50$ yo & 377 & 19.55 & 1551 & 80.45 & 4.96 & $4.00-6.15$ \\
\hline $51-64$ yo & 401 & 32.05 & 850 & 67.95 & 9.63 & $7.75-11.98$ \\
\hline \multicolumn{7}{|l|}{ Physical activity } \\
\hline Low & 274 & 13.05 & 1825 & 86.95 & Ref & \\
\hline Moderate & 464 & 13.14 & 3066 & 86.86 & 1.00 & $0.85-1.18$ \\
\hline High & 426 & 13.37 & 2760 & 86.63 & 1.02 & $0.87-1.20$ \\
\hline \multicolumn{7}{|l|}{ IMT } \\
\hline Not suffer from obesity & 969 & 11.97 & 7127 & 88.03 & Ref & \\
\hline Suffer from obesity & 195 & 27.12 & 524 & 72.88 & 2.73 & $2.29-3.26$ \\
\hline \multicolumn{7}{|l|}{ Smoking habit } \\
\hline Do not smoke & 283 & 9.49 & 4694 & 85.18 & 1.65 & $1.43-1.91$ \\
\hline Used to smoke & 64 & 19.81 & 259 & 80.19 & 2.35 & $1.74-3.17$ \\
\hline Smoke & 283 & 9.49 & 2698 & 90.15 & Ref & \\
\hline
\end{tabular}


Table 3. Multiple Logistic Regression

\begin{tabular}{|c|c|c|c|}
\hline Variables & $p$ value & AOR & $\begin{array}{l}\text { 95\% CI } \\
\text { Lower Upper }\end{array}$ \\
\hline \multicolumn{4}{|l|}{ Sleep quality } \\
\hline Good & & Ref & \\
\hline Poor & 0.000 & 1.39 & $1.20-1.61$ \\
\hline \multicolumn{4}{|l|}{ Sex } \\
\hline Male & & Ref & \\
\hline Female & 0.046 & 1.23 & $1.00-1.51$ \\
\hline \multicolumn{4}{|l|}{ Age } \\
\hline $15-26$ yo & & Ref & \\
\hline $27-38$ yo & 0.000 & 1.89 & $1.51-2.36$ \\
\hline $39-50$ yо & 0.000 & 4.93 & $3.96-6.13$ \\
\hline $51-64$ yo & 0.000 & 9.48 & $7.59-11.83$ \\
\hline \multicolumn{4}{|l|}{ Physical activity } \\
\hline Low & & Ref & \\
\hline Moderate & 0.165 & 0.88 & $0,74-1.05$ \\
\hline High & 0.787 & 0.97 & $0.82-1.16$ \\
\hline \multicolumn{4}{|l|}{ IMT } \\
\hline Not suffer from obesity & & Ref & \\
\hline Suffer from obesity & 0.000 & 2.27 & $1.87-2.75$ \\
\hline \multicolumn{4}{|l|}{ Smoking habit } \\
\hline Do not smoke & 0.001 & 1.46 & $1.17-1.83$ \\
\hline Used to smoke & 0.000 & 1.78 & $1.30-2.45$ \\
\hline Smoke & & Ref & \\
\hline
\end{tabular}

Table 3 showed that poor sleep quality had 1.39 times higher odds of experiencing hypertension compared to respondents who had good sleep quality after being controlled by variables of gender, age, smoking status, physical activity, and nutritional status (AOR poor-good sleep quality $=1.39,95 \%$ CI $1.20-1.61$ $\mathrm{p}=0.000)$.

\section{DISCUSSIONS}

Sleep patterns are one of the factors that influence hypertension. Hypertension can occur due to increased heart rate and blood pressure for 24 hours, increased salt retention, and the sympathetic nervous system due to the short duration of sleep and lasts for an extended period. It can lead to structural adaptations of the cardiovascular system and cause an increase in blood pressure
(Gangwisch et al., 2006). Lack of sleep can cause disruption of metabolism and endocrine which can result in impaired cardiovascular. The blood pressure of people who have normal sleep time will normally decrease. During sleep, there is a decrease in sympathetic activity which causes this condition. A decrease in blood pressure during sleep will not occur if someone has a sleep disorder, and it can cause an increased risk of hypertension (Calhoun \& Harding, 2010).

Someone who has a bad sleep pattern tends to be at risk of developing hypertension compared to people who have a good sleep pattern. Several studies have reported the condition that people who have sleep disorders have a higher risk of hypertension compared to people who do not have sleep disorders. All age groups and genders can influence it 
(Fobian et al., 2018). The conditions of high or low blood pressure can occur in individuals due to sleep disorders, whereas normal pressure conditions can occur if there is no sleep disturbance (Moi et al., 2017). The increased blood pressure occurs due to changes in the primary stress hormone (cortisol) and the sympathetic nervous system as a result of poor sleep quality (Amanda et al., 2016). In addition, someone will experience depression, and body mass index increases if he/she has disturbed sleep quality for an extended period (Lu et al., 2015).

Exercise and fatigue are some of the factors influencing sleep quality. A lot of sleep time is highly needed by individuals who have many activities. It is necessary to balance the energy that has come out. The slow-wave sleep stage of individuals who experience fatigue will be shortened, so they will sleep faster than people who do not experience fatigue. They are very likely to have difficulty sleeping due to fatigue caused by the heavy workload or stress of working. Teenagers or school-age children tend to experience this condition. Poor sleep quality that is owned by teenagers or school-age children due to high demands and physical conditions can cause stress, causing sleep time to be disrupted (Lumantow et al., 2016).

Someone who is considered to have poor sleep quality is not only seen from the disruption of sleep but also the length of sleep time. There are several factors that result from short sleep time, including an increase in the hemodynamic burden that occurs gradually over 24 hours, increased salt retention and salt lust, the duration of exposure to physical and psychosocial stress factors while awake, and increased sympathetic nervous system activity. Moreover, there is a cause of the duration of the exposure to factors that result from short sleep time, namely structural adaptation of the cardiovascular system such as left ventricular hypertrophy and arterial constriction resulting in increased blood pressure balance (Folkow, 2001).
Lack of fulfillment of sleep time needs influences the incidence of (Winarni \& Hartanto, 2016). It occurs since physiologically, the nervous system, and organs of the human body are affected by the fulfillment of sleep time. Sleep is needed by the body to restore body organs, including the nervous system that has been used in carrying out various activities all day. In addition, sleep also has benefits in the process of protein synthesis. People tend to be emotional and have poor concentration due to lack of sleep. It is also difficult for them to make decisions. The disruption of sleep patterns also affects health conditions, one of which is hypertension.

In this study, it was found that there was a significant relationship between sleep quality and the incidence of hypertension among a working-age population with $\mathrm{p}$-value 0.002 . The results of this research were in line with a research conducted by Roshifanni (2016), which pointed out that there was a significant relationship between sleep quality and the incidence of hypertension with p-value 0.000 (Roshifanni, 2016). In a research conducted by Luthfi, Azmi \& Erkadius (2017), it was found that there was a difference between systolic and diastolic blood pressure in people with good sleep quality and poor sleep quality. The results of the statistical analysis also proved that there was a significant relationship between sleep quality with systolic and diastolic blood pressure with p-value 0.000 (Luthfi B et al., 2017).

The results of this study showed that people who had poor sleep quality had a 1.39 times greater risk of developing hypertension compared to people who had good sleep quality. This research was in line with the research of Alfi \& Yuliwar (2018), which emphasized that poor sleep quality had a strong relationship with blood pressure (Alfi \& Yuliwar, 2018). The results of this research were also supported by a research conducted by Martini, Roshifanni, \& Marzela (2018), which argued that people with poor sleep patterns had 9.022 times greater risk of 
hypertension compared to people who had good sleep patterns (Martini et al., 2018).

$$
\text { A research conducted by Bansil }
$$

(2011) suggested a different result. It concluded that hypertension was not influenced by the quality of individual sleep but rather the age and work of the individual was a factor that caused the stress that resulted in the incidence of hypertension. Blood pressure gradually increased due to increased sympathetic nerve activity caused by increased stress (Bansil et al., 2011).

As getting older, a person usually has a decreased quality of sleep since sleep time needs are different based on age (Marlina, 2010). Research conducted in the United States in $8-10 \%$ of community groups found that people who had less than 5 hours of sleep rest that was $50 \%$ and people who had sleep disorders which were equal to $20 \%$ had a major influence on cardiovascular disruption and also resulted in an increased risk of hypertension (Vgontzas et al., 2009).

Insignificant changes in cardiac output at night experienced by someone are the effect of sympathetic activity in blood vessels. This causes a relationship between sleep and hypertension. A decrease in normal nocturnal arterial blood pressure can occur due to decreased peripheral vascular resistance. There is a significant increase in the difference between sympathetic nerve activity and Rapid Eye Movement (REM) when a person wakes up and sleeps. Sensitivity is increased during sleeping. When the REM has passed, the blood pressure is almost close to the awake level. Increased blood pressure maintenance during the REM period starts at the end of the sleep period from the night before is more useful to do because sleep patterns are very influential in this. Hypertension can occur due to hypertension disorders that occur in sleep quality and non-dipping prehypertension caused by abnormal sleep (Liu et al., 2016).

Rising blood pressure can be influenced by the bad habits which are frequently done, such as poor sleep quality or short duration of sleep. Poor quantity and quality of sleep can result in damage to one's memory and cognition. In addition, poor quantity and quality of a person can also cause the body to experience interference. If it is not treated promptly, complications such as depression or other mood disorders, strokes, and heart problems can be very likely to arise (Potter \& Perry, 2012).

This research has a limitation that the measurement of hypertension status only utilizes the question of whether the respondents have been diagnosed by a doctor/paramedic/nurse/midwife about whether or not they have hypertension. It can cause bias. However, it has a strength that the research sample is large.

\section{CONCLUSIONS}

There is a relationship between sleep quality and the incidence of hypertension among the working-age population in Indonesia. It is necessary to strengthen information about health promotion regarding the prevention of hypertension in the community, especially good time management to maintain sleep quality and the need for health programs on prevention of hypertension carried out by the ministry of health to the community through existing health workers.

\section{REFERENCES}

Alfi, W. N., \& Yuliwar, R. (2018). The Relationship between Sleep Quality and Blood Pressure in Patients with Hypertension. Jurnal Berkala Epidemiologi, $\quad 6(1), \quad 18$. https://doi.org/10.20473/jbe.v6i12018.18 $-26$

Amanda, H., Prastiwi, S., \& Sutriningsih, A. (2016). Hubungan kualitas tidur dengan tingkat kekambuhan hipertensi pada lansia di kelurahan tlogomas Kota Malang Hafiez. Nursing News, 1, 358368.

Bansil, P., Kuklina, E. V., Merritt, R. K., \& Yoon, P. W. (2011). Associations between sleep disorders, sleep duration, 
quality of sleep, and hypertension: Results from the National Health and Nutrition Examination Survey, 2005 to 2008. Journal of Clinical Hypertension, 13(10), 739-743. https://doi.org/10.1111/j.1751-

7176.2011.00500.x

Calhoun, D. A., \& Harding, S. M. (2010). Sleep and hypertension. Chest, 138(2), 434-443.

https://doi.org/10.1378/chest.09-2954

Fobian, A. D., Elliott, L., \& Louie, T. (2018).

A Systematic Review of Sleep, Hypertension, and Cardiovascular Risk in Children and Adolescents. Current Hypertension Reports, 20(5). https://doi.org/10.1007/s11906-0180841-7

Folkow, B. (2001). Mental Stress and its Importance for Cardiovascular Disorders; Physiological Aspects, "From-Mice-toMan". Scand Cardiovasc J, 35(3), 16372.

Forde, C. (2005). Scoring the International Physical Activity Questionnaire (IPAQ) Exercise Prescription for the Prevention and Treatment of Disease.

Gangwisch, J. E., Heymsfield, S. B., BodenAlbala, B., Buijs, R. M., Kreier, F., Pickering, T. G., Rundle, A. G., Zammit, G. K., \& Malaspina, D. (2006). Short sleep duration as a risk factor for hypertension: Analyses of the first National Health and Nutrition Examination Survey. Hypertension, 47(5), 833-839. https://doi.org/10.1161/01.HYP.0000217 362.34748.e0

Javaheri, S., Storfer-Isser, A., Rosen, C. L., \& Redline, S. (2008). Sleep Quality and Elevated Blood Pressure in Adolescents. Circulation, 118(10), 1034-1040. https://doi.org/10.1161/CIRCULATION AHA.108.766410

Javaheri, S., Zhao, Y. Y., Punjabi, N. M., Quan, S. F., Gottlieb, D. J., \& Redline, S. (2018). Slow-Wave sleep is associated with incident hypertension: The sleep heart health study. Sleep, 4l(1), 1-7. https://doi.org/10.1093/sleep/zsx179

Kementerian Kesehatan Republik Indonesia. (2019). Laporan Nasional RISKESDAS 2018. Badan Penelitian dan Pengembangan Kesehatan.

Liu, R. Q., Qian, Z., Trevathan, E., Chang, J. J., Zelicoff, A., Hao, Y. T., Lin, S., \& Dong, G. H. (2016). Poor sleep quality associated with high risk of hypertension and elevated blood pressure in China: Results from a large population-based study. Hypertension Research, 39(1), 5459. https://doi.org/10.1038/hr.2015.98

Lu, K., Chen, J., Wu, S., Chen, J., \& Hu, D. (2015). Interaction of sleep duration and sleep quality on hypertension prevalence in adult Chinese males. Journal of Epidemiology, 25(6), 415-422. https://doi.org/10.2188/jea.JE20140139

Lumantow, I., Rompas, S., \& Onibala, F. (2016). Hubungan Kualitas Tidur Dengan Tekanan Darah Pada Remaja Di Desa Tombasian Atas Kecamatan Kawangkoan Barat. Jurnal Keperawatan UNSRAT, 4(1), 111237.

Luthfi B, M., Azmi, S., \& Erkadius, E. (2017). Hubungan Kualitas Tidur dengan Tekanan Darah pada Pelajar Kelas 2 SMA Negeri 10 Padang. Jurnal Kesehatan Andalas, 6(2), 318. https://doi.org/10.25077/jka.v6i2.698

Mahiroh, H., Astutik, E., \& Pratama, R. A. (2019). The Association of Body Mass Index, Physical Activity and Hypertension in Indonesia. Jurnal Ners, 14(1), 16. https://doi.org/10.20473/jn.v14i1.12811

Marlina. (2010). Faktor - Faktor Yang Mempengaruhi Tidur Pada Lanjut Usia Di Desa Meunasah Balek Kecamatan Kota Meureudu Kabupaten Pidie Jaya. $J$ Ilmu Keperawatan Dan Kebidanan, 1(4), $1-21$.

Martini, S., Roshifanni, S., \& Marzela, F. (2018). Pola Tidur yang Buruk Meningkatkan Risiko Hipertensi. Media Kesehatan Masyarakat Indonesia, 14(3), 
297.

https://doi.org/10.30597/mkmi.v14i3.418 1

Martuti. (2009). Merawat dan Menyembuhkan Hipertensi. Kreasi Wacana.

Moi, M. A., Widodo, D., \& Sutriningsih, A. (2017). Hubungan Gangguan Tidur Dengan Tekanan Darah Pada Lansia. Nursing News : Jurnal Ilmiah Mahasiswa Keperawatan, 2(2), 124-131.

National Heart, Lung, \& BI. (2003). The Seventh Report of the Joint National Committee on Prevention, Detection, Evaluation, and Treatment of High Blood Pressure. U.S. Department of Health and Human Services.

Potter, P. A., \& Perry, A. (2012). Buku ajar fundamental keperawatan konsep, proses, dan praktik (4th ed., Vol. 2) (Komalasari, translator). EGC.

Roshifanni, S. (2016). Risiko Hipertensi Pada Orang Dengan Pola Tidur Buruk (Studi di Puskesmas Tanah Kalikedinding Surabaya). Jurnal Berkala Epidemiologi, 4(3), 408-419.

Setiawan, D., \& Purnomo, A. E. (2016). Hubungan Antara Pola Tidur Dengan Tekanan Darah Pada Warga Usia 30-60
Tahun Di RT 05 RW 02 Kelurahan Kedung-Kandang Kecamatan KedungKandang Kota Malang. Journal of Nursing Care \& Biomolecular, 1(2), 6469.

Vgontzas, A. N., Liao, D., Bixler, E. O., Chrousos, G. P., \& Vela-Bueno, A. (2009). Insomnia with objective short sleep duration is associated with a high risk for hypertension. Sleep, 32(4), 491497.

https://doi.org/10.1093/sleep/32.4.491

Winarni, W., \& Hartanto, P. Y. (2016). Hubungan Antara Pemenuhan Kebutuhan Istirahat Tidur Dengan Kejadian Hipertensi pada Masyarakat di Dusun Celep Kidul Kelurahan Dagen Kecamatan Jaten Karanganyar. Jurnal Ilmu Kesehatan Kosala, 4(2), 197-203.

World Health Organization. (2013). A Global Brief on Hypertension: Silent Killer, Global Public Health Crisis. World Health Organization.

World Health Organization. (2019). Obesity. World Health Organization.

World Health Organization. (2020). Hypertension. 